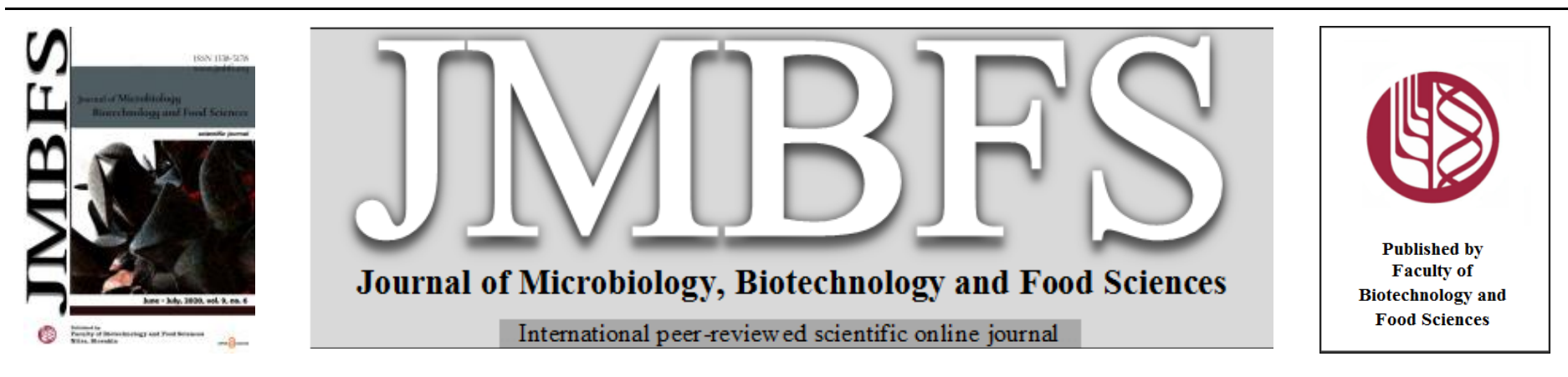

\title{
OPTIMISATION OF THE MICROWAVE-ASSISTED EXTRACTION OF NATURAL ANTIOXIDANTS FROM DEFATTED BLACK RICE BRAN OF ORYZA SATIVA L. CV. HOMNIN
}

\section{Anek Halee ${ }^{1}$, Piyawan Supavititpatana ${ }^{2}$, Khanitta Ruttarattanamongkol ${ }^{1}$, Nitipong Jittrepotch ${ }^{l}$, Kamonwan Rojsuntornkitti ${ }^{1}$ and Teeraporn Kongbangkerd ${ }^{* 1}$}

\author{
$\operatorname{Address(es):~}$ \\ ${ }^{1}$ Department of Agro-Industry, Faculty of Agriculture, Natural Resources and Environment, Naresuan University, Phitsanulok 65000, Thailand. \\ ${ }^{2}$ Division of Food Science and Technology, Faculty of Food and Agricultural Technology, Pibulsongkram Rajabhat University, Phitsanulok 65000, Thailand.
}

*Corresponding author: teerapornk@nu.ac.th

doi: $10.15414 / j m b f s .2020 .9 .6 .1134-1140$

ARTICLE INFO

Received 27. 11. 2018

Revised 23. 1. 2020

Accepted 4. 2. 2020

Published 1. 6. 2020

Regular article

open $\odot$ access

\section{INTRODUCTION}

Rice (Oryza sativa L.) is the principle cereal food in Asia and staple food of nearly half of the world's population. Rice is the most common crop, and very important in the world. In Asia, rice is so central to the culture that the word is almost synonymous with food

(Danielski et al., 2005; Xia et al., 2006; Lu et al., 2008). It is commonly been believed that rice provides more health benefits than other carbohydrate sources since it contains antioxidant compounds and several nutrients (Vijittra et al., 2011). Furthermore, the consumption of colored rice increased dramatically (Kong and Lee, 2010). It has been reported that colored rice comprised higher levels of antioxidative content in its seed coat and pericarp than white rice (Yodmanee et $\boldsymbol{a l} .$, 2011). Rice bran contains the strongest antioxidants and significant amount of natural phytochemicals (Godber \& Juliano, 2004). The major of antioxidative compounds in the colored rice seed coat are phenolic compounds, mainly anthocyanins, a subgroup of flavonoids (Abdel et al., 2006). Phenolic compounds provide health benefits forasmuch their antioxidant activities, which have inhibited effects on carcinogenesis and mutagenesis (Vattem et al., 2005). In addition, black rice or purple rice has been known to relieve the risk of chronic diseases; such as, cardiovascular, cancers problems, diabetes and its complications (Xia et al., 2006; Walter and Marchesan, 2011). It also has been reported that black rice has more therapeutic values and nutritional compared to white rice (Choi et al., 2007; Chen et al., 2006).

Oryza sativa L. CV. Homnin rice is one type of black rice and it has higher nutritional value than other rice varieties such as protein, minerals and vitamins (Suzuki et al., 2004). Furthermore, the amount of vitamin B, vitamin E, calcium, niacin, iron, zinc and magnesium were higher when compared to non-colored rice and and it could be important fountainhead of anthocyanin. Anthocyanins in natural's source offer health benefits in anti-cancer, decrease of dyslipidemia, reduction of coronary heart disease, prevention of heart disease, liver protection and improvement of visual acuity (Mazza and Miniati, 1993; Chen et al., 2006; Lee, 2010). Rice bran is an abundant and underutilized by-product of rice milling, and constitutes around $10 \%$ of the total weight of rough rice, which is generally used for animal feed. In addition, it offers nutritional value and antioxidants, as well as unpolished rice, such as tocopherols, phytic acid tocotrienols and tricin and also pigments in which major of them are stored in the pericarp or bran of the rice grain, and the distinct pigmented are related to different colors; such as, red, black and purple (Hu et al., 2003; Vijittra et al., 2011; Anek et al., 2018).

Extraction of antioxidative compounds has become an alternative method for improving by-product from colored rice to be a more valuable product.
Howsoever, the antioxidant stability of the extract is an affair of large concern due to the effects of the extraction procedure and also the charge of extraction. Therefore, the extraction temperature needs to be considered due to some instability of the antioxidative compounds with heat (Benchahem et. al., 2015). For those antioxidantive compounds that react to alkaline compounds and acidic aqueous solvents, neutral solvents have been used for extraction, so to break the cell wall and cell membranes and at the meanwhile dissolve the water-soluble antioxidants. Normally, acetic acid, citric acid and hydrochloric acid are selected for acidulating the extraction solvent but using citric acid is also safe for consumer (Li et al., 2012; Mateus and Freitas, 2009; Anek et al., 2018) Usually, conventional solvent extraction of antioxidative compounds are long time and solvent consuming while the efficiency is low. In addition, thermal extraction with a long time could cause the degradation of anthocyanins and then decrease the antioxidant capacity of the extracts (Lapornik et al. 2005). Microwave-assisted extraction (MAE) utilizes the energy of microwaves to cause molecular rotation and movement of aqueous solution with a permanent dipole leading to a very fast heating of the sample and the solvent, providing advantages such as reduced extraction time, improved efficiency, high level of automation and low solvent consumption compared to conventional solvent extraction methods (Sun et al., 2007).

The objective of this research was to investigate the optimization conditions of microwave-assisted extraction on total phenolic and total flavonoid content as well as to evaluate the antioxidant capacity from the defatted Homnin rice bran extract. Therefore, natural antioxidative compound and also the natural color from the extracts of by-product materials could then be probably used to supersede synthetic colors and antioxidants in foods for safety concern.

\section{MATERIALS AND METHODS}

\section{Rice bran sample}

Homnin rice bran (must be within 24 hours after milling) was collected from the Nongpingkai Rice Mill Community enterprise, Kamphaeng Phet province, Thailand. The Homnin rice bran was sieved to separate the bran from the rice grains and then vacuum packed in laminate bag and stored at $-20^{\circ} \mathrm{C}$.

\section{Chemicals and reagents}

(+)-Catechin hydrate, Gallic acid, 6-hydroxy-2,5,7,8- tetramethylchroman-2carboxylic acid (Trolox), 2,2-diphenyl- 1-picrylhydrazyl (DPPH), were purchased from Sigma-Aldrich (St. Louis, MO, USA). Folin-Ciocalteu's reagent, 
methanol, sodium carbonate and ethanol were purchased from Merck (Darmstadt, Germany). Aluminum chloride hydrate was purchased from Ajax Finechem Pty Ltd. (Auckland, New Zealand). All chemicals and other reagents used in this study were analytical grade.

\section{Sample preparation}

Homnin rice bran ground to passed through 100 mesh sieves and heated by using oven at $100 \pm 3^{\circ} \mathrm{C}$ for 15 minutes (Memmert UNE 500, Germany) to inactivate the endogenous lipase (Juliano, 1985; Anek et al., 2018). Briefly, Homnin rice bran was defatted twice using hexane in bran to solvent ratio of 1:10 at a setting of 100 rpm in a rotary shaker for 2 hours and filter through Whatman No. 1 filter pape at room temperature (RT). The defatted Homnin rice bran (DHRB) was air-dried overnight (12 hours). The DHRB was packed in laminate bags and stored at 20oC. (Kim et al., 2013; Anek et al., 2018)

\section{Extraction of defatted Homnin rice bran (DHRB)}

Two grams of DHRB was placed into Erlenmeyer flasks and extracted with different proportion of power energy from 298-800 watt, citric acid concentration in water from $0.033-0.117 \mathrm{~mol} / \mathrm{dm}^{3}(1: 20 \mathrm{w} / \mathrm{v})$, and extraction time from 13-147 seconds (Table 1). The mixtures were carried out in microwave reactor. Then, the extracts were centrifuged at $10^{\circ} \mathrm{C}$ and $5,000 \mathrm{rpm}$ for $10 \mathrm{~min}$ and the supernatants were collected and stored at $-20^{\circ} \mathrm{C}$ until use.

Table 1 Variables and their levels employed in a central composite design for optimization of DHRB extracts

\begin{tabular}{llllll}
\hline \multirow{2}{*}{ Variable } & \multicolumn{6}{l}{ Range and levels (coded) } & & \\
\cline { 2 - 6 } & $\begin{array}{l}\boldsymbol{- \alpha ( -} \\
\mathbf{1 . 6 8})\end{array}$ & $\mathbf{- 1}$ & $\mathbf{0}$ & $+\mathbf{1}$ & $+\boldsymbol{\alpha}(+\mathbf{1 . 6 8})$ \\
\hline Power energy (Watt) & 298 & 400 & 550 & 700 & 800 \\
$\begin{array}{l}\text { Citric acid concentration } \\
\left(\mathrm{mol} / \mathrm{dm}^{3}\right)\end{array}$ & 0.033 & 0.05 & 0.75 & 0.1 & 0.117 \\
Extraction time (second) & 13 & 40 & 80 & 120 & 147 \\
\hline
\end{tabular}

Determination of total phenolic content (TP)

TP of each DHRB sample was determined using the colorimetric method described by Singleton et al (1999) with modifications.

Briefly, $100 \mu$ of DHRB extract solution were mixed with distilled $\mathrm{H}_{2} \mathrm{O}(3 \mathrm{ml})$ and $10 \% \mathrm{v} / \mathrm{v}$ of Folin- Ciocalteu's reagent for $6 \mathrm{~min}$. Sodium carbonate solution ( $2 \mathrm{~mL}, 7.5 \%$ ) was added to the mixture. The absorbance of the resulting solution was measured after 2 hours at $750 \mathrm{~nm}$. (Genersis10, Thermo Scientific, USA) Gallic acid was used as a standard and expressed as mg gallic acid per gram of DHRB dry matter (mg/g DM)

\section{Determination of total flavonoid content (TF)}

TF was determined according to the method described by Yang et al. (2009) and Anek et al. (2018) with some modifications. $100 \mu$ of the extract was mixed with $1.25 \mathrm{ml}$ of distilled $\mathrm{H}_{2} \mathrm{O}$, and then mixed with sodium nitrite solution $(75 \mu \mathrm{l}$, $5 \% \mathrm{w} / \mathrm{v})$. After $6 \mathrm{~min}$, aluminum chloride solution $(150 \mu \mathrm{l}$ of $10 \% \mathrm{w} / \mathrm{v})$ was added, the mixture was allowed to stand for another $5 \mathrm{~min}$, and sodium hydroxide solution $(0.5 \mathrm{ml}, 1.0 \mathrm{M})$ was then added. The reaction solution was well mixed and kept for $15 \mathrm{~min}$, and the absorbance was determined at $510 \mathrm{~nm}$ using a UVVis spectrophotometer (Genersis10, Thermo Scientific, USA) compared to the catechin standard. The TF of the extracts was expressed as mg of catechin equivalents per gram of the DHRB dry matter (mg CE/g DM).

\section{Determination of total anthocyanin content (TA)}

Total anthocyanin content in the samples were measured using a spectophotometricpH differential method of Finocchiaro et al. (2010) and Anek et al. (2018) with some modifications. Aliquots of appropriately diluted solutions were mixed thoroughly with potassium chloride buffer $(25 \mathrm{mM}, \mathrm{pH} 1.0)$. The absorbance of the mixture was then measured at 520 and $700 \mathrm{~nm}$ against distilled water blank. The aliquots of appropriately diluted solutions were then combined similarly with sodium acetate buffer $(400 \mathrm{mM}, \mathrm{pH} 4.5)$, and the absorbance of these solutions was measured at the same wavelengths.

The TA was calculated as equivalent to cyanindin-3-glucoside according to the following equation:

Total anthocyanin content $=(\Delta \mathrm{A} \times \mathrm{MW} \times \mathrm{DF} \times 1000) / \mathrm{e})$

Where

$\Delta \mathrm{A}=(\mathrm{Abs} \lambda 520-\mathrm{Abs} \lambda 700) \mathrm{pH} 1.0-(\mathrm{Abs} \lambda 520-\mathrm{Abs} \lambda 700) \mathrm{pH} 4.5$ MW (molecular weight $)=449.2 \mathrm{~g} / \mathrm{mol}$ for cyanidin-3-glucoside $\mathrm{DF}=$ dilution factor

$\mathrm{e}=$ is the molar extinction coefficient, equaling $26,900 \mathrm{~L} / \mathrm{mol} \mathrm{cm}$ for cyanidin-3-glucoside.
$1000=$ conversion factor from $\mathrm{g}$ to $\mathrm{mg}$.

The total anthocyanin was expressed as mg of cyanidin-3-glucoside equivalents per 1 gram of DHRB

\section{DPPH radical scavenging assay}

The DPPH assay was carried out with slight modification (Brand-Williams et al. 1995; Zhang et al, 2007; Anek et al., 2018). $100 \mu$ l of the DHRB extract was added to $3 \mathrm{ml}$ of $0.1 \mathrm{mM}$ DPPH solution (prepared in methanol). After $30 \mathrm{~min}$ of incubation at room temperaturein the dark, the absorbance at $517 \mathrm{~nm}$ was measured. The DPPH free radical scavenging activities of the DHRB extracts were expressed as $\mu \mathrm{M}$ of the Trolox equivalents (TE) per gram of rice bran dry matter using a standard curve of Trolox ( $\mu \mathrm{mol}$ TE/g DM).

\section{Experimental design and data analysis}

The optimum of extraction parameters from DHRB by using RSM was employed in the optimum study. A central composite design (CCD) was used to investigate the effect of independent variables as power energy $\left(\mathrm{X}_{1}\right)$, citric acid concentration $\left(\mathrm{X}_{2}\right)$, extraction time $\left(\mathrm{X}_{3}\right)$ to be optimized for the extraction (Table 2). The complete design consisted of 20 experimental points including eight factorial points, six axial points and six center points. The data was fitted with a second order polynomial equation, which expressed total phenolic content $\left(Y_{1}\right)$, total flavonoid $\left(Y_{2}\right)$, anthocyanin $\left(Y_{3}\right)$ and DPPH $\left(Y_{4}\right)$. The equation was as follows:

$$
Y=b_{0}+\sum_{i=1}^{3} b_{i} X_{i}+\sum_{i=1}^{3} b_{i j} X_{i}^{2}+\sum_{i=1}^{3} \sum_{j=1}^{3} a_{i j} X_{i} X_{j}
$$

Where $Y$ indicates the response variables, $b_{0}$ is a constant, $b_{i}, b_{i i}$ and $b_{i j}$ are the linear, quadratic and interactive coefficients, respectively. $X_{i}$ and $X_{j}$ are the levels of the independent variables. Three-dimensional surface response plots were generated by varying two variables within the experimental range and holding the other constant at the central point. The analytical steps as analysis of variance (ANOVA), regression analysis and coefficients of the response surface equation were estimated by using Design expert v 6.10. Fisher's F-test determined the second-order polynomial model equation at a probability $(\mathrm{P})$ of $0.001,0.01$ or 0.05 . The test of statistical significance was based on the total error criteria with a confidence level of $95 \%(\mathrm{p}<0.05)$.

\section{Verification of model}

The predictive performance of the models depending on the combined effect of power energy $\left(\mathrm{X}_{1}\right)$, citric acid concentration $\left(\mathrm{X}_{2}\right)$, extraction time $\left(\mathrm{X}_{3}\right)$ was validated with an optimum extraction condition as predictive models of RSM The criterion of fitting efficiency of data to the model was the average mean deviation Eq. (2).

$$
E \%=\frac{1}{\eta_{e}} \sum_{i=1}^{n}\left\|\frac{V_{E}-V_{P}}{V_{E}}\right\| \times 100
$$

Where $\eta_{e}$ is the number of experiment data, $V_{P}$ is the predicted value and $V_{E}$ is the experimental value (Hossain et al., 2012).

\section{RESULTS AND DISCUSSION}

Optimization of DHRB extraction using MAE such as power energy, citric acid concentration and extraction time variables on total phenolic content (TP), total flavonoids (TF), anthocyanin (AT) and antioxidant activitiy (DPPH) of DHRB extracts.

The experimental data from central composite design demonstrates that the power energy $\left(\mathrm{X}_{1}\right)$, citric acid concentration $\left(\mathrm{X}_{2}\right)$ and extraction time $\left(\mathrm{X}_{3}\right)$ had revealed quadratic effect on TP $\left(\mathrm{Y}_{1}\right), \mathrm{TF}\left(\mathrm{Y}_{2}\right)$, AT $\left(\mathrm{Y}_{3}\right)$, DPPH $\left(\mathrm{Y}_{4}\right)$ (Table 1). The observed values of TP, TF and AT of DHRB extracts varied from 21.97 to $86.78 \mathrm{mg} \mathrm{GAE} / \mathrm{g} \mathrm{DM}, 15.00$ to $78.33 \mathrm{mg} \mathrm{CE} / \mathrm{g} \mathrm{DM}$ and 4.16 to $16.98 \mathrm{mg} \mathrm{C} 3 \mathrm{G} / \mathrm{g}$ $\mathrm{DM}$, respectively. The antioxidant activities of the DHRB extracts determined by the DPPH method was between $17.22-40.27 \mu \mathrm{mol}$ TE/g DM.

The experimental data allowed the development of mathematic equations resulting the predicted results. The second order models and regression coefficients of the intercept, linear, quadratic and interaction terms of model had significant effects of $\mathrm{P}<0.0001, \mathrm{P}<0.001, \mathrm{P}<0.01$ or $\mathrm{P}<0.05$ (Table 3). For all responses, the quadratic polynomial models were significant with $\mathrm{P}$-values for $\mathrm{P}<0.0001$.

The analysis of variance (ANOVA) to assess the goodness of fit of all parameters of the models and to estimate the statistic significant of the factor and interactions between terms is shown in Table 3. The R-squared $\left(\mathrm{R}^{2}\right)$ values were in the range between 0.962 to 0.989 and were in agreement with the Adjust R-squared (Adj $\mathrm{R}^{2}$ ) values in the range between 0.927 to 0.968 . Both $\mathrm{R}^{2}$ and Adj $\mathrm{R}^{2}$ values 
indicated that the general availability and accuracy of the polynomial model were sufficient (Han, et al., 2016).

Table 2 Experimental design of central composite design (CCD) of TP, TF, AT and DPPH of DHRB extracts

\begin{tabular}{|c|c|c|c|c|c|c|c|}
\hline \multirow[b]{2}{*}{$\begin{array}{l}\text { Run } \\
\text { no. }\end{array}$} & \multicolumn{3}{|l|}{ Factors } & \multicolumn{4}{|l|}{ Responses } \\
\hline & $\begin{array}{l}\left(X_{I}\right)^{\mathrm{a}} \text { Power } \\
\text { energy (Watt) }\end{array}$ & $\begin{array}{l}\left(X_{2}\right)^{\mathrm{b}} \text { Citric acid } \\
\text { concentration } \\
\left(\mathrm{mol} / \mathrm{dm}^{3}\right)\end{array}$ & $\begin{array}{l}\left(X_{3}\right)^{\mathrm{c}} \\
\text { Extraction } \\
\text { time (second) } \\
\end{array}$ & $\begin{array}{l}\text { TP } \\
(\mathrm{mg} \quad \mathrm{GAE} / \\
\mathrm{g} \mathrm{DM}) \\
\end{array}$ & $\begin{array}{l}\text { TF } \\
(\mathrm{mg} \mathrm{CE} / \mathrm{g} \\
\mathrm{DM})\end{array}$ & $\begin{array}{l}\text { TA } \\
(\mathrm{mg} \mathrm{C} 3 \mathrm{G} / \\
\mathrm{g} \mathrm{DM})\end{array}$ & $\begin{array}{ll}\text { DPPH } & \\
(\mu & \text { mol } \\
\text { TE/g DM })\end{array}$ \\
\hline 1 & -1 & 1 & -1 & 26.97 & 25.00 & 6.40 & 59.54 \\
\hline 2 & 0 & $-1.682(\alpha)$ & 0 & 50.48 & 41.67 & 10.94 & 85.54 \\
\hline 3 & 0 & 0 & $-1.682(\alpha)$ & 45.34 & 30.82 & 9.58 & 80.21 \\
\hline 4 & 1 & -1 & 1 & 62.34 & 52.37 & 13.99 & 85.58 \\
\hline 5 & -1 & -1 & -1 & 42.90 & 25.00 & 7.71 & 68.58 \\
\hline 6 & $1.682(\alpha)$ & 0 & 0 & 80.76 & 57.67 & 16.19 & 95.03 \\
\hline 7 & 0 & 0 & $1.682(\alpha)$ & 43.40 & 23.57 & 8.36 & 66.36 \\
\hline 8 & -1 & -1 & 1 & 32.64 & 15.00 & 4.16 & 44.89 \\
\hline 9 & 1 & 1 & 1 & 63.59 & 61.73 & 14.35 & 95.56 \\
\hline 10 & -1 & 1 & 1 & 21.97 & 20.19 & 5.17 & 45.11 \\
\hline 11 & 1 & 1 & -1 & 50.06 & 48.33 & 10.74 & 90.25 \\
\hline 12 & 0 & $1.682(\alpha)$ & 0 & 38.25 & 34.07 & 9.82 & 82.38 \\
\hline 13 & 1 & -1 & -1 & 55.26 & 47.47 & 11.65 & 86.97 \\
\hline 14 & $-1.682(\alpha)$ & 0 & 0 & 36.30 & 26.57 & 5.57 & 40.27 \\
\hline 15 & 0 & 0 & 0 & 84.79 & 67.30 & 16.25 & 99.36 \\
\hline 16 & 0 & 0 & 0 & 85.40 & 70.83 & 17.02 & 102.69 \\
\hline 17 & 0 & 0 & 0 & 83.32 & 71.11 & 17.22 & 99.83 \\
\hline 18 & 0 & 0 & 0 & 86.59 & 78.33 & 16.42 & 101.97 \\
\hline 19 & 0 & 0 & 0 & 85.17 & 75.00 & 16.98 & 103.25 \\
\hline 20 & 0 & 0 & 0 & 86.78 & 74.67 & 16.89 & 104.26 \\
\hline
\end{tabular}

Level of power energy: $-\alpha(298),-1(400), 0(550), 1(700),+\alpha(800)$

b Level of citric acid concentration: $-\alpha(0.033),-1(0.050), 0(0.075), 1(0.100),+\alpha(0.117)$

c Level of extraction time: $-\alpha(13),-1(40), 0(80), 1(120),+\alpha(147)$

Table 3 Second order polynomial equations and regression coefficients and analysis of the models for four response variables

\begin{tabular}{|c|c|c|c|c|}
\hline \multirow{2}{*}{ Coefficient } & \multicolumn{4}{|c|}{ Responses } \\
\hline & TP & TF & AT & DPPH \\
\hline$b_{0}$ & $85.42^{\mathrm{d}}$ & $72.76^{\mathrm{d}}$ & $16.81^{\mathrm{d}}$ & $101.93^{\mathrm{d}}$ \\
\hline$X_{1}$ & $13.29^{\mathrm{d}}$ & $12.96^{\mathrm{d}}$ & $3.31^{\mathrm{d}}$ & $17.01^{\mathrm{d}}$ \\
\hline$X_{2}$ & $-3.74^{\mathrm{d}}$ & $0.19^{\mathrm{ns}}$ & $-0.20^{\mathrm{ns}}$ & $-0.06^{\mathrm{ns}}$ \\
\hline$X_{3}$ & $0.15^{\mathrm{ns}}$ & $-0.64^{\mathrm{ns}}$ & $-0.06^{\mathrm{ns}}$ & $-4.21^{\mathrm{d}}$ \\
\hline$X_{I}^{2}$ & $-9.99^{\mathrm{d}}$ & $-10.15^{\mathrm{d}}$ & $-2.18^{\mathrm{d}}$ & $-12.37^{\mathrm{d}}$ \\
\hline$X_{2}^{2}$ & $-15.00^{\mathrm{d}}$ & $-11.66^{\mathrm{d}}$ & $-2.35^{\mathrm{d}}$ & $-6.61^{\mathrm{d}}$ \\
\hline$X_{3}^{2}$ & $-15.00^{\mathrm{d}}$ & $-15.43^{\mathrm{d}}$ & $-2.85^{\mathrm{d}}$ & $-10.38^{d}$ \\
\hline$X_{12}$ & $2.83^{\mathrm{b}}$ & $0.63^{\mathrm{ns}}$ & $-0.03^{\mathrm{ns}}$ & $2.76^{\mathrm{b}}$ \\
\hline$X_{13}$ & $4.48^{\mathrm{d}}$ & $4.14^{\mathrm{ns}}$ & $1.34^{\mathrm{d}}$ & $5.26^{\mathrm{d}}$ \\
\hline$X_{23}$ & $1.46^{\mathrm{a}}$ & $1.71^{\mathrm{ns}}$ & $0.45^{\mathrm{a}}$ & $2.00^{\mathrm{a}}$ \\
\hline \multicolumn{5}{|c|}{ Regression model } \\
\hline$F$-value & 326.17 & 27.97 & 165.10 & 244.24 \\
\hline$P$-value & $<0.0001$ & $<0.0001$ & $<0.0001$ & $<0.0001$ \\
\hline \multicolumn{5}{|l|}{ Lack of fit } \\
\hline$F$-value & $3.03^{\mathrm{ns}}$ & $3.32^{\mathrm{ns}}$ & $2.67^{\mathrm{ns}}$ & $1.00^{\mathrm{ns}}$ \\
\hline$P$-value & 0.125 & 0.107 & 0.153 & 0.500 \\
\hline$R^{2}$ & 0.987 & 0.962 & 0.963 & 0.976 \\
\hline$R^{2}-a d j$ & 0.964 & 0.927 & 0.957 & 0.951 \\
\hline
\end{tabular}

${ }^{\text {ns }}$ Not significant

a Significant at $P<0.05$

b Significant at $P<0.01$

Significant at $P<0.001$

d Significant at $P<0.0001$

The lack of fit indicates the variation of the data around the fitted model. If the model were significant, it did not fit the data well (Ghafari et al., 2009; Han et al., 2016). The P-value for lack of fit presents in Table 3, showing the nonsignificant, implying model had a significant correlation between the responses and variables. Therefore, the four responses suggested quadratic polynomial models could be adequately used to predict models. These results were corresponding with the finding of González-Centeno et al, (2014) who reported the significant of regression and non-significant lack of fit of model would be fitted to the experimental data which were suitable to predict within the system.

The effects of power energy, citric acid concentration and extraction time on TP, TF, AT and DPPH values of DHRB extract are depicted with the three dimension response surface plots. Fig.1-4 presents three dimension response surface showing interaction of two variables, while another variable was fixed constant at their respective zero level. The results indicated that power energy, citric acid concentration and extraction time had significantly affected $(\mathrm{P}<0.01)$ by the quadratic terms of TP, TF, AT and DPPH.

\section{Response surface of TP, TF, AT and DPPH}

The response surface of TP, TF, AT and DPPH as presented in Table 1 demonstrates that power energy $\left(X_{1}\right)$, citric acid concentration $\left(X_{2}\right)$ and extraction time $\left(X_{3}\right)$ had a quadratic effect. The second-order polynomial equations of TP, $\mathrm{TF}, \mathrm{AT}$ and DPPH were attained as follows:

$$
\begin{array}{cc}
\mathrm{Y}_{1}=85.42+13.29 \mathrm{X}_{1}-3.74 \mathrm{X}_{2}+0.15 \mathrm{X}_{3}-9.99 \mathrm{X}_{1}{ }^{2}-15.00 \mathrm{X}_{2}{ }^{2}-15.00 \\
\mathrm{X}_{3}{ }^{2}+2.83 \mathrm{X}_{1} \mathrm{X}_{2}+4.48 \mathrm{X}_{1} \mathrm{X}_{3}+1.46 \mathrm{X}_{2} \mathrm{X}_{3} & (3) \\
\mathrm{Y}_{2}=72.76+12.96 \mathrm{X}_{1}+0.19 \mathrm{X}_{2}-0.64 \mathrm{X}_{3}-10.15 \mathrm{X}_{1}{ }^{2}-11.66 \mathrm{X}_{2}{ }^{2}- & (4) \\
15.43 \mathrm{X}_{3}{ }^{2}+0.63 \mathrm{X}_{1} \mathrm{X}_{2}+4.14 \mathrm{X}_{1} \mathrm{X}_{3}+1.71 \mathrm{X}_{2} \mathrm{X}_{3} & (5) \\
\mathrm{Y}_{3}=16.81+3.31 \mathrm{X}_{1}+0.20 \mathrm{X}_{2}-0.06 \mathrm{X}_{3}-2.18 \mathrm{X}_{1}{ }^{2}-2.35 \mathrm{X}_{2}{ }^{2}-2.85 \\
\mathrm{X}_{3}{ }^{2}-0.03 \mathrm{X}_{1} \mathrm{X}_{2}+1.34 \mathrm{X}_{1} \mathrm{X}_{3}+0.45 \mathrm{X}_{2} \mathrm{X}_{3} & (5) \\
\mathrm{Y}_{4}=101.93+17.01 \mathrm{X}_{1}-0.06 \mathrm{X}_{2}-4.21 \mathrm{X}_{3}-12.37 \mathrm{X}_{1}{ }^{2}-6.61 \mathrm{X}_{2}{ }^{2}- \\
10.38 \mathrm{X}_{3}{ }^{2}+2.76 \mathrm{X}_{1} \mathrm{X}_{2}+5.26 \mathrm{X}_{1} \mathrm{X}_{3}+2.00 \mathrm{X}_{2} \mathrm{X}_{3}
\end{array}
$$

(6)

As depicted in Table 3, each parameter had more significant influence on TP, TF and AT contents. All of equations were extremely significant $(\mathrm{P}<0.0001)$ and the 
lack of fit was non-significant $(\mathrm{P}>0.05)$. Hence the results indicated that the equations were reasonable. ANOVA of model regression coefficients were significance. The effects of power energy $\left(X_{I}\right)$ citric acid concentration $\left(X_{2}\right)$ from linear, quadratic $\left(\mathrm{X}_{1}^{2}, \mathrm{X}_{2}^{2}\right.$ and $\left.\mathrm{X}_{3}^{2}\right)$ and interaction $\left(\mathrm{X}_{1} \mathrm{X}_{2}, \mathrm{X}_{1} \mathrm{X}_{3}\right.$ and $\left.\mathrm{X}_{2} \mathrm{X}_{3}\right)$ of TP were significant $(\mathrm{P}<0.05)$, while the effects of citric acid concentration $\left(X_{2}\right)$, extraction time $\left(X_{3}\right)$ of TF and AT model from linear and interaction were nonsignificant but all quadratic parameters were significant $(P<0.05)$. The $R^{2}$ for al responses TP, TF and AT were $0.987,0.962$ and 0.963 , respectively, indicated that the model could explain 98.7, 96.2 and 96.3\% variability of the response variables. These results were in accordance with González-Centeno et al. (2014) and Sai-Ut et al. (2015) who found that the $R^{2}$ values had to be higher than 0.80 which indicated a good correlation between responses and independent variable of model. The Adj $R^{2}$ of TP, TF and AT $(0.964,0.927$ and 0.957$)$ were agreed with the $R^{2}$. The P-value for lack of fit shows non-significant, implying the effects of independent variables on the TP, TF and AT were described by the obtained models.

The effect of independent variables i.e., power energy $\left(X_{1}\right)$, citric acid concentration $\left(\mathrm{X}_{2}\right)$ and extraction time $\left(\mathrm{X}_{3}\right)$ on antioxidant activity obtained from DHRB with MAE was investigated. Antioxidant activity of DHRB determined by DPPH methods ranged between 40.27-104.26 $\mu \mathrm{mol}$ TE/g DM. The ANOVA indicated that three quadratic polynomial equations were highly significant $(\mathrm{P}<0.0001)$ while lack of fits from three equations were not significant $(\mathrm{P}>0.05)$ indicating the models were good fitted to the experimental data. These results were confirmed by coefficient of determination $\left(\mathrm{R}^{2}\right)$ of DPPH models, $(0.976)$, which explained good regression values of all variances of the data

The response surface three dimension plots are the representation of regression equation indicating the relationship between dependent and independen variables. The response surface plots are different shapes indicating whether the variables or mutual interactions are significant or not (Liu et al., 2013). The response surface plots based on equations $3-6$, showing the effects of two variables within the experiment and another one variable was kept constant at their optimum values are presented in Fig. 1-4. The effects of power energy and citric acid concentration on TP, TF and AT contents are shown in Fig. 1a, 2a and $3 \mathrm{a}$, respectively. Fig. 1a, 2a and 3a demonstrate the power energy $\left(X_{I}\right)$, citric acid concentration $\left(X_{2}\right)$ and their reciprocal interaction on TP, TF and AT contents, where the extraction time $\left(X_{3}\right)$ was fixed at 80 seconds. The results indicated that TP, TF and AT increased slowly with increasing citric acid concentration while the increase of power energy resulted the rapidly increasing of TP, TF and AT content. However, beyond $0.075 \mathrm{~mol} / \mathrm{dm}^{3}$ and 625 watts, TP content decreases slightly.
(1)

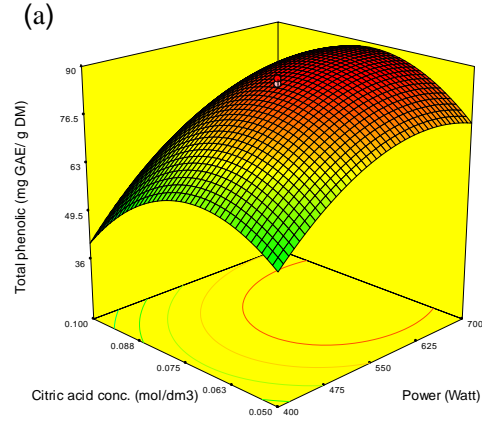

(b)

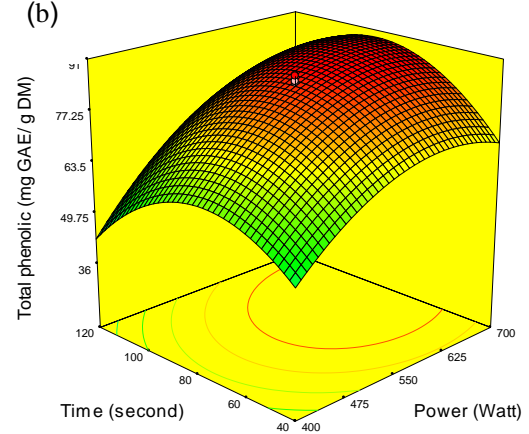

(c)

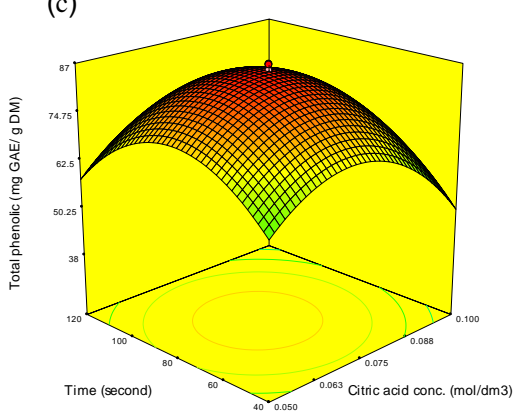

Figure 1 Response surface plots of DHRB showing the effects of power energy,citric acid concentration and extraction time on total phenolic content

The response surface three dimension plots in Fig. 1b, $2 b$ and $3 b$, which kept the citric acid concentration at zero level $\left(0.075 \mathrm{~mol} / \mathrm{dm}^{3}\right)$, showed that TP, TF and AT contents increased with increasing extraction time at the initial stage and then slightly decreased of trend, while the increase of power energy resulted the rapidly increasing of $\mathrm{TP}, \mathrm{TF}$ and $\mathrm{AT}$ content. However, beyond 80 second and 625 watts, TP, TF and AT content was decreased slightly. As shown in Fig. 1c,
$2 \mathrm{c}$ and $3 \mathrm{c}, \mathrm{TP}, \mathrm{TF}$ and $\mathrm{AT}$ contents were increased when citric acid concentration increased from 0.050 to $0.075 \mathrm{~mol} / \mathrm{dm}^{3}$ and the extraction time from 40 to 90 second, respectively and then they began to decrease afterwards.

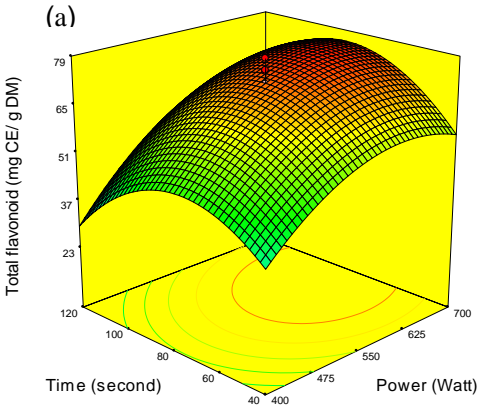

(b)

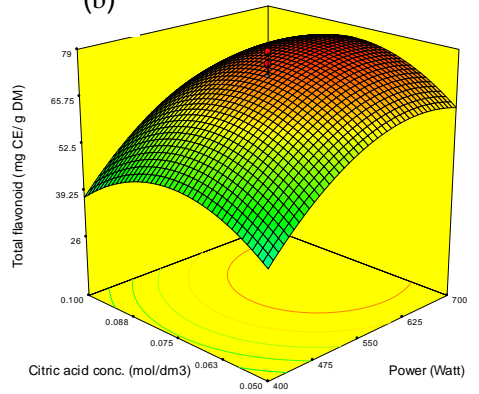

(c)

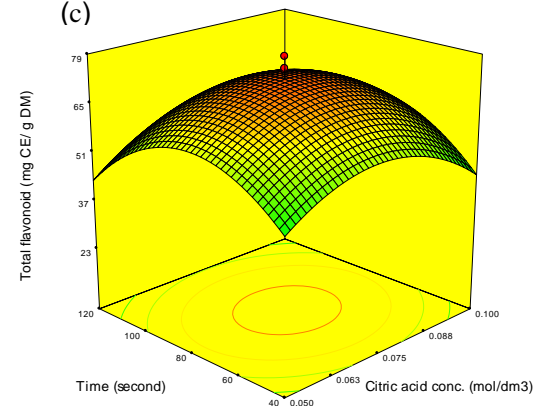

Figure 2 Response surface plots of DHRB showing the effects of power energy, citric acid concentration and extraction time on total flavonoid content

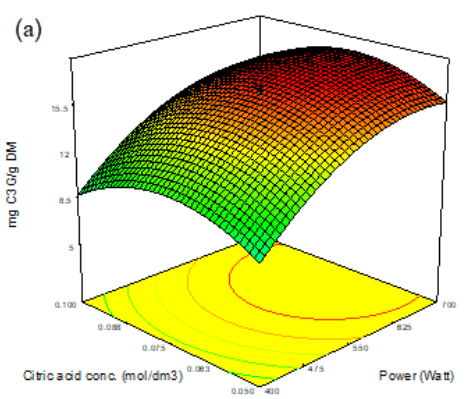

(b)

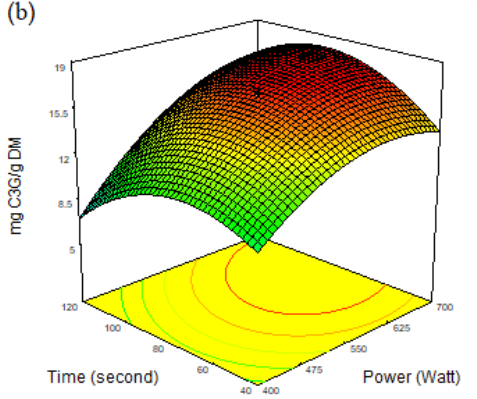

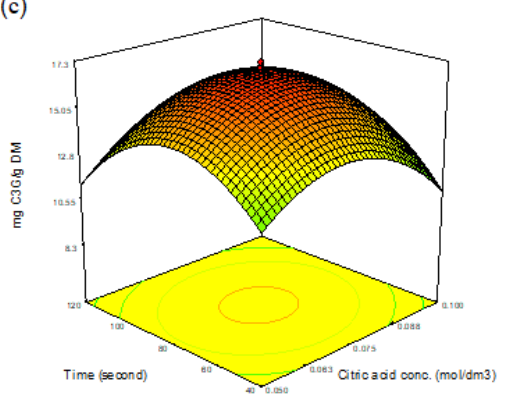

Figure 3 Response surface plots of DHRB showing the effects of power energy, citric acid concentration and extraction time on anthocyanin content 
The relationship between the extraction factors and antioxidant activity investigated by three dimensional response surface plots, are presented in Fig. 4 The three-dimension response surface plots of DPPH assay were similar to the trend of TP, TF and AT. The response surface plots showed that DPPH increased slowly with increasing citric acid concentration as well as extraction time at the initial stage and then the antioxidant activity slightly decreased, while the increase of power energy resulted the rapidly increase of DPPH. However, beyond 625 watts and $0.075 \mathrm{~mol} / \mathrm{dm}^{3}$, the DPPH decreased slightly. Our results were in concordance with Bachir Bey et al, (2014) who reported the polarity played an important role in antioxidant activity. This might be assumed to the fact that citric acid is a strong organic acid, and there are three hydrogen ions $\left(\mathrm{H}^{+}\right)$which can be ionized, so the $\mathrm{pH}$ value is much lower in the solution with higher citric acid concentration. In addition, microwave can make those polar ions move in the solution, and then heat the solution and there is much more $\mathrm{H}^{+}$ in low $\mathrm{pH}$ solution, consequently, the low $\mathrm{pH}$ solution has higher temperature than the high $\mathrm{pH}$ solution (Li et al., 2012). It was noticed that both citric acid concentration and power energy had significant interaction effect on DPPH. (a)

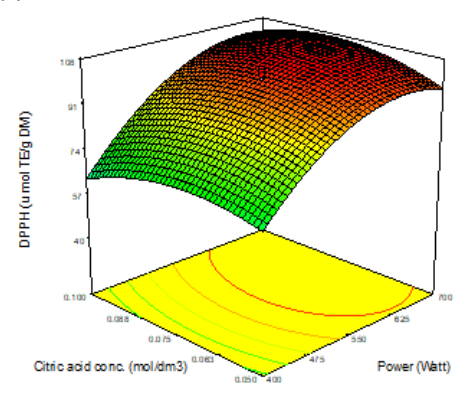

(b)

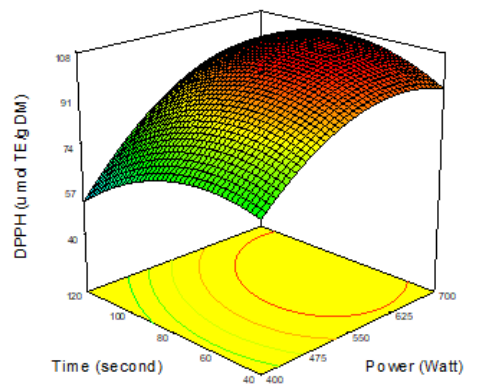

(c)

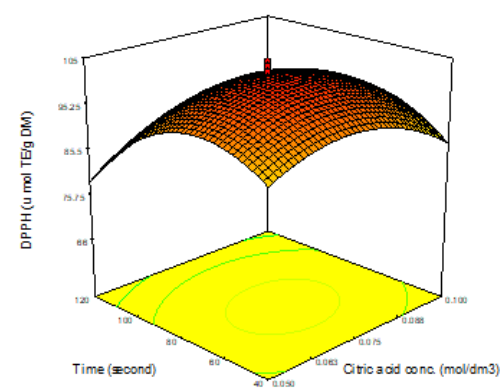

Figure 4 Response surface plots of DPPH of DHRB as affected by power energy, citric acid concentration and extraction time

The similar results were also reported in the extraction of anthocyanin content from grape peel by $\mathbf{L i}$ et al, (2012), found that increasing power energy and citric acid concentration resulted in higher anthocyanin. In addition, the factors that mostly affected the total anthocyanin content were the concentration of citric acid, extraction time, power of the microwave, and ratio between the solvent and the sample, respectively. Citric acid concentration affecting anthocyanin extraction contents which may be attributed to the change of polarity of solvent as citric acid concentration was changed. More polar phenolic compounds may be extracted according to "like dissolves like" principle and solvent would extract compounds which have similar polarity with solvents (Chew et al., 2011; Gong et al., 2012). Basically, phenolics could easily be dissolved from material cells when solvent polarity are similar to phenolics (Sai-Ut et al., 2015). Furthermore, using acids to assist the phytochemical extraction would help disrupt the cell walls and cell membrane of the plant samples, consequently, anthocyanins could be released effectively in higher amounts.

When increasing citric acid concentration, the $\mathrm{pH}$ of solvent was lower and the TP, TF and AT were decreased. The result were similar to Bahar et al. (2009) studied the effect of solvent and citric acid concentration on the extraction of phenolic compounds from olives and found that when using a higher concentration of citric acid, the phenolic content was decreased. This was due to phenolic generally found in most plants include 3 different groups such as a free form, bound form and conjugated form. The bound form is chiefly found in the layer of lignin extracted by using alkaline or acidic hydrolysis, whilst the free form is the group that the structure is gently stable so that when using acidic extraction of phenolic compounds, it would be partially damaged. Howsoever, when using high concentration of acid, the plant cell walls and cell membrane were ruptured, so that the more active ingredients were released.

From the investigation of influence of extraction time on TP, TF and AT content found that TP, TF and AT were increased in the early stage until they reacted the maximum release and then they were decreased since longer extraction causes more degradation of the extract due to phenolics could more react with surrounding environment such as heat, oxygen and light (Chew et al., 2011).

\section{Optimum conditions from DHRB and model validation}

The RSM procedure is used to determine the experimental factors and levels which would allow to obtain an extract with high phytochemicals and antioxidant activities. The predictive ability of the models was examined by extraction at optimum conditions. Table 4 shows the optimum extracting condition which the three factors obtained from the model were followings: 648 watts of power energy, $0.076 \mathrm{~mol} / \mathrm{dm}^{3}$ of citric acid concentration and extraction time of 83 seconds and the experimental values of $90.59 \mathrm{mg} \mathrm{GAE} / \mathrm{g} \mathrm{DM}\left(Y_{1}\right), 77.53 \mathrm{mg}$ $\mathrm{CE} / \mathrm{g} \mathrm{DM}\left(Y_{2}\right), 18.82 \mathrm{mg} \mathrm{C} 3 \mathrm{G} / \mathrm{g} \mathrm{DM}\left(Y_{3}\right)$ and $109.35 \mu \mathrm{mol} \mathrm{TE} / \mathrm{g} \mathrm{DM}\left(Y_{4}\right)$, were obtained. The experimental results were close to the predicted values of $89.89 \mathrm{mg}$ GAE/g DM $\left(Y_{1}\right), 76.98 \mathrm{mg} \mathrm{CE} / \mathrm{g} \mathrm{DM}\left(Y_{2}\right), 18.08 \mathrm{mg} / \mathrm{g} \mathrm{DM}\left(Y_{3}\right), 107.72 \mu \mathrm{mol}$ $\mathrm{TE} / \mathrm{g} \mathrm{DM}\left(Y_{4}\right)$, by the regression models. Validation step was done to ensure that the predicted results were not biased towards the practical value with each response to obtain maximum values (Yim et al., 2012). The predicted values match well with the experimental values obtained by using optimum extracting conditions which the validation between the predicted and experimental values were within an acceptable error range as depicted by average mean deviation with the E\% range between -1.67 to $3.95 \%$ (Table 4). Comparing with the conventional extraction method, MAE provided higher extraction efficiency as Halee et al. (2018) studied the extraction of defatted Homnin rice bran and found that TP, TF, AT and DPPH of the methanolic extract with $0.1 \mathrm{~mol} / \mathrm{dm}^{3}$ of citric acid were $86.63 \mathrm{mg}$ of GAE/g DM, $14.67 \mathrm{mg} \mathrm{CE} / \mathrm{g} \mathrm{DM}, 6.18 \mathrm{mg} \mathrm{C} 3 \mathrm{G} / \mathrm{g} \mathrm{DM}$. and $29.02 \mu \mathrm{mol} \mathrm{TE} / \mathrm{g} \mathrm{DM}$, respectively.

Table 4 Validation of predicted and experimental values of the TP, TF, AT and DPPH values from DHRB extract with different extraction conditions

\begin{tabular}{|c|c|c|c|c|}
\hline \multirow{2}{*}{ Responses } & \multicolumn{4}{|c|}{ Extracting conditions } \\
\hline & Worse $^{\mathrm{a}}$ & $\operatorname{High}^{\mathrm{b}}$ & Medium $^{c}$ & Optimum $^{\mathrm{d}}$ \\
\hline \multicolumn{5}{|c|}{ Predicted value } \\
\hline $\mathrm{TP}$ & 44.51 & 63.92 & 85.42 & 89.89 \\
\hline $\mathrm{TF}$ & 29.49 & 54.53 & 72.77 & 76.98 \\
\hline AT & 8.15 & 14.24 & 16.81 & 18.08 \\
\hline DPPH & 69.84 & 95.32 & 101.94 & 107.72 \\
\hline \multicolumn{5}{|c|}{ Experimental value } \\
\hline TP & $46.02 \pm 0.49$ & $65.08 \pm 0.43$ & $86.59 \pm 0.85$ & $90.59 \pm 0.46$ \\
\hline $\mathrm{TF}$ & $30.08 \pm 0.56$ & $56.03 \pm 0.34$ & $72.61 \pm 0.46$ & $77.53 \pm 0.55$ \\
\hline AT & $8.02 \pm 0.43$ & $14.62 \pm 0.66$ & $17.06 \pm 0.52$ & $18.82 \pm 0.49$ \\
\hline DPPH & $70.68 \pm 1.06$ & $97.16 \pm 1.79$ & $100.26 \pm 2.52$ & $109.35 \pm 2.62$ \\
\hline \multicolumn{5}{|l|}{ E\% } \\
\hline TP & 3.27 & 1.78 & 1.35 & 0.77 \\
\hline $\mathrm{TF}$ & 1.96 & 2.69 & 0.21 & 0.71 \\
\hline AT & -1.57 & 2.63 & 1.45 & 3.95 \\
\hline DPPH & 1.18 & 1.89 & -1.67 & 1.49 \\
\hline
\end{tabular}

${ }^{a}$ Worse(run 5): $X_{1}: X_{2}: X_{3}$ as $400: 0.05: 40$

${ }^{\mathrm{b}}$ High (run 15) : $X_{1}: X_{2}: X_{3}$ as $700: 0.10: 120$

${ }^{\mathrm{c}}$ Medium (run 9) $: X_{1}: X_{2}: X_{3}$ as $550: 0.075: 80$

${ }^{\mathrm{d}}$ Optimum : $X_{1}: X_{2}: X_{3}$ as $648: 0.076: 83$ 
The obtained optimum condition of power energy was in the same range as Chen et al. (2016) who reported the optimum power energy of 704 watts for extraction of antioxidant from tangerine peels. In addition Oussaid $\boldsymbol{e t}$ al. (2018) reported the values of 600 watts of power energy and 69 second for extraction of phenolic compound from Scirpus holoschoenus L. The increase of power energy level beyond 500 watt could have speed-up the mass transfer of intracellular bioactive compounds. However, excessive microwave power could lead to the degradation of the total flavonoid content chargeable for the antioxidant capacity (Dahmoune et al., 2014; Spigno and De Faveri, 2009).

\section{CONCLUSION}

This study reveals that the optimum microwave assisted extraction condition was following: 648 watt of power energy, $0.076 \mathrm{~mol} / \mathrm{dm}^{3}$ of citric acid concentration and 83 second of extraction time and the experimental values of TP, TF, AT and antioxidant activity (DPPH) were $90.59 \mathrm{mg}$ GAE/g DM, $77.53 \mathrm{mg} \mathrm{CE} / \mathrm{g} \mathrm{DM}$, $18.82 \mathrm{mg} \mathrm{C} 3 \mathrm{G} / \mathrm{g} \mathrm{DM}, 109.35 \mu \mathrm{mol} \mathrm{TE} / \mathrm{g} \mathrm{DM}$, respectively. The predicted values matched well with the experimental values which the validation between the experimental values and predicted values were within an acceptable error range as depicted by average mean deviation with the $\mathrm{E} \%$ ranged from -1.85 to 3.27 .

Acknowledgement: The study was made possible through the financial support provided by the Doctoral Research Scholarship, Faculty of Agriculture, Natural Resources and Environment, Naresuan University. This research was also supported by Food Science and Technology Program, Faculty of Science and Technology, Kamphaeng Phet Rajabhat University for operation of the scienctific laboratory equipment.

\section{REFERENCES}

Abdel-Aal. E.S. M., Young, J.C. and Rabalski, I. 2006. Anthocyanin composition in black, blue, pink, purple, and red cereal grains. Journal of Agricultural and Food Chemistry, 54, 4696-4704. http://dx.doi.org/ 10.1021/jf0606609

Halee, A., Supavititpatana, P., Ruttarattanamongkol, K., Jittrepotch1, N., Rojsuntornkitti, K. and Kongbangkerd, T. Effects of solvent types and citric acid concentrations on the extraction of antioxidants from the black rice bran of Oryza sativa L. CV. Hom Nin. Journal of microbiology, biotechnology and food sciences, 8,765-769. http://dx.doi.org/10.15414/jmbfs.2018.8.2.765-769

Bachir-Bey, M., Meziant, L., Benchikh, Y. and Louaileche, H. 2014. Deployment of response surface methodology to optimize recovery of dried dark fig (Ficus carica L., var. Azenjar) total phenolic compounds and antioxidant activity. International Food Research Journal, 21(4), 1477-1482. https://doi.org/10.1016/j.foodchem.2014.04.054

Bahar A., Fariba, D. and Patrizia P., 2009.The effect of citric acid on the phenolic contents of olive oil. Journal of Food Chemistry, 116, 617-623. https://doi.org/10.1016/j.foodchem.2009.02.077

Benchahem, S., Karrila, S. J. and Karrila, T. T. 2015. Effect of pretreatment with ultrasound on antioxidant properties of black glutinous rice water extracts International Food Research Journal, 22, 2371-2380.

Brand-Williams, W., Cuvelier, M. E., and Berset, C. 1995. Use of a free radical method to evaluate antioxidant activity. Journal of LWT - Food Science and Technology, 28, 25-30. http://dx.doi.org/10.1016/S0023-6438(95)80008-5

Chen, P. N., Kuo, W. H., Chiang, C. L., Chiou, H. L., Hsieh, Y. S. and Chu ,S. C. 2006. Black rice anthocyanins inhibit cancer cells invasion via repressions of MMPs and u-PA expression. Journal of Chemico-Biological Interactions, 163, 218-229. http://dx.doi.org/10.1016/j.cbi.2006.08.003

Chen, R., Jin, C., Tong, Z., Lu, J., Tan, L., Tian, L. and Chang, Q. 2016. Optimization extraction, characterization an antioxidant activities of pectin polysaccharide from tangerine peels. Journal of Carbohydrate polymer, 136, 187-197. https://doi.org/10.1016/j.carbpol.2015.09.036

Chew, K.K., Ng, S.Y., Thoo, Y.Y., Khoo, M.Z., Wan Aida, W.M. and Ho, C.W 2011. Effect of ethanol concentration, extraction time and extraction temperature on the recovery of phenolic compounds and antioxidant capacity of Centella asiaitca extracts. International Food Research Journal, 18, 571-578.

Choi, Y., Jeong, H. S., and Lee, J. 2007. Antioxidant activity of methanolic extracts from some grains consumed in Korea. Journal of Food Chemistry, 103,130-138. http://dx.doi.org/10.1016/j.foodchem.2006.08.004

Dahmoune, F., Spigno, G., Moussi, K., Remini, H., Cherbal, A., and Madani, K. 2014. Pistacia lentiscus leaves as a source of phenolic compounds: microwaveassisted extraction optimized and compared with ultrasound-assisted and conventional solvent extraction. Industrial. Crops Products, 61, 31-40. https://doi.org/10.1016/j.indcrop.2014.06.035

Danielski, L., Zetzl, C., Hense, H. and Brunner, G. 2005. A process line for the production of raffinated rice oil from rice bran. Journal of Supercritical Fluids, 34, 133-141. http://dx.doi.org/10.1016/j.supflu.2004.11.006

Finocchiaro, F., Ferrari, B. and Gianinetti, A., 2010. A study of biodiversity of flavonoid content in the rice caryopsis evidencing simultaneous accumulation of anthocyanins and proanthocyanidins in a black-grained genotype. Journal of Cereal Science, 51, 28-34. http://dx.doi.org/ 10.1016/j.jcs.2009.09.003
Ghafari, S., Aziz, A. H., Isac, M.H., and Zinatizadeh, A.A. 2009. Application of response surface methodology (RSM) to optimize coagulation-flocculation treatment of leachate using poly-aluminum chloride (PAC) and alum. Journal of Hazardous Materials, 163 ,

650-656.

https://doi.org/10.1016/j.jhazmat.2008.07.090

Godber, S. and Juliano, B. 2004. Rice lipids. In:Champagne,E,T. (ed). Rice Chemistry and Technology (3rd Edn) St Paul, MN: AACC International, Inc.

Gong, Y., Liu, X., He, W.H., Xu, H.G., Yuan, F. and Gao, Y.X. 2012. Investigation into the antioxidant activity and chemical composition of alcoholic extracts from defatted marigold (Tagetes erecta L.) residue. Fitoterapia, 83,481489. https://doi.org/10.1016/j.fitote.2011.12.013

González-Centeno, M.R., Knoerzer, K., Sabarez, H., Simal, S., Rosselló, C., and Femenia, A. 2014. Effect of acoustic frequency and power density on the aqueous ultrasonic-assisted extraction of grape pomace (Vitis vinifera L.) - A response surface approach. Ultrasonics Sonochemistry, 21, 2176-2184. https://doi.org/10.1016/j.ultsonch.2014.01.021

Halee, A., Supavititpatana, P., Ruttarattanamongkol, K., Jittrepotch, N., Rojsuntornkitti, K. and Kongbangkerd,T. (2018). Effects of solvent types and citric acid concentrations on the extraction of antioxidants from the black rice bran of Oryza sativa L. Cv. Hom nin. Journal of Microbiology, Biotechnology and Food Sciences. 8(2), 765-769. https://doi.org/10.15414/jmbfs.2018.8.2.765769

Han, N., Wang, L., Song, Z., Lin, J., Ye, C., Liu, Z., and Yin, J. 2016 Optimization and antioxidant activity of polysaccharides from Plantago depressa. International Journal of Biological Macromolecules, 93, 644-654. https://doi.org/10.1016/j.ijbiomac.2016.09.028

Hu, C., Zawistowski, J., Ling, W. and Kitts, D. D. 2003. Black rice (Oryza sativa L. indica) pigmented fraction suppresses both reactive oxygen species and nitric oxide in chemical and biological model systems. Journal of Agricultural Food Chemistry, 51,5271-5277. http://dx.doi.org/10.1021/jf034466n

Juliano, B. 1985. Rice bran. In B. Juliano (Ed.), Rice bran, in Rice Chemistry and Technology. St. Palu, MN: The American Association of Cereal Chemist. (pp. 659).

Kim, W. C, Nicholas, M.H., Shahid, I., and Maznah, I., 2013. Isolation and antioxidative properties of phenolics-saponins rich fraction from defatted rice bran. Journal of Cereal Science, 57, 480-485. http://dx.doi.org/ 10.1016/j.jcs.2013.02.002

Kong, S., and Lee, J. 2010. Antioxidants in milling fractions of black rice cultivars. Journal of Food Chemistry, 120, 278-281. http://dx.doi.org/10.1016/j.foodchem.2009.09.089

Lapornik, B., Prošek, M., and Wondra, A.G., 2005. Comparison of extracts prepared from plant by-products using different solvents and extraction time. Journal of Food Engineering, 71(2), 214-222. https://doi.org/10.1016/j.jfoodeng.2004.10.036

Lee, J. H. 2010. Identification and quantification of anthocyanins from the grains of black rice (Oryza sativa L.) varieties. Journal of Food Science and Biotechnology, 19, 391-397. http://dx.doi.org/10.1007/s10068-010-0055-5

Li, Y., Han, L., Ma, R., Xu, X., Zhao, C., Wang, Z., Chen, F., and Hu, X. 2012 Effect of energy density and citric acid concentration on anthocyanins yield and solution temperature of grape peel in microwave-assisted extraction process. Journal of Food Engineering,109, 274-280. http://dx.doi.org/10.1016/j.jfoodeng.2011.09.021

Liu, Y., Wei, S., and Liao, M. 2013. Optimization of ultrasonic extraction of phenolic compounds from Euryale ferox seed shells using response surface methodology. Industrial Crops and Products, 49, 837-843. https://doi.org/10.1016/j.indcrop.2013.07.023

Lu, Z., Kou, W., Du, B., Wu, Y., Zhao, S., and Brusco, O. A., 2008. Effect of Xuezhikang, and extract from red yeast Chinese rice, on coronary events in a Chinese population with previous myocardial infarction. The American Journal of Cardiology, 101, 1689-1693. http://dx.doi.org/10.1016/j.amjcard.2008.02.056 Mateus, N. and Freitas, V. 2009. Anthocyanins as food colorants. Anthocyanins: biosynthesis, functions, and applications. New York: Springer Verlag p.304. http://dx.doi.org/10.1007/978-0-387-77335-3

Mazza, G. and Miniati, E. 1993.Anthocyanins in Fruits, Vegetables and Grains London: CRC press. http://dx.doi.org/10.1002/food. 19940380317

Oussaida, S., Madania, K., Houalib, K., Renduelesc, M. and Diazc, M. 2018 Optimized microwave-assisted extraction of phenolic compounds from Scirpus holoschoenus and its antipseudomonal efficacy, alone or in combination with Thymus fontanesii essential oil and lactic acid. Food and Bioproducts Processing, 110, 85-95. https://doi.org/10.1016/j.fbp.2018.04.008

Sai-Ut, S., Benjakul, S., Kraithong, S., and Rawdkuen, S. 2015. Optimization of antioxidants and tyrosinase inhibitory activity in mango peels using response surface methodology. LWT - Food Science and Technology, 64, 742-749. https://doi.org/10.1016/j.lwt.2015.06.003

Singleton, V. L., Orthofer, R. and Lamuela-R, R. M., 1999. Analysis of total phenols and other oxidation substrates and antioxidants by means of folinciocalteu reagent. Journal of Methods in Enzymology, 299, 152-178. http://dx.doi.org/10.1016/S0076-6879(99)99017-1

Sun, Y., Liao, X., Wang, Z., Hu, X. and Chen, F. 2007. Optimization of microwave-assisted extraction of anthocyanins in red raspberries and 
identification of anthocyanin of extracts using high-performance liquid chromatography. Journal of European Food Research and Technology, 225, 511-523.

Spigno, G. and Faveri, D.M. 2009. Microwave-assisted extraction of tea phenols: A phenomenological study. Journal of Food Engineering, 93, 210-217. https://doi.org/10.1016/j.jfoodeng.2009.01.006

Suzuki, M., Kimur, T., Yamagishi, K., Shinmoto, H., and Yamak, K. 2004.

Comparison of Mineral Contents in 8 Cultivars of Pigmented Brown rice. Nippon Shokuhin Kagaku Kogaku Kaishi, 51, 424-427. http://dx.doi.org/10.3136/nskkk.51.424

Vattem, D. A., Ghaedian, R. and Shetty, K. (2005). Enhancing health benefits of berries through phenolic antioxidant enrichment: Focus on cranberry. Asia Pacific Journal of Clinical Nutrition, 14, 120-130.

Vijittra, L., Wirangrong, T., Panawan, S., Ratchanee, K., Sugunya, W.,and Apichart, W. 2011. Chemopreventive properties of the bran extracted from a newly-developed Thai rice: The Riceberry. Journal of Food Chemistry, 125, 978-985. http://dx.doi.org/10.1016/j.foodchem.2010.09.09

Walter, M. and Marchesan, E. 2011. Phenolic compounds and antioxidant activity of rice. Journal of Brazilian Archives of Biology and Technology, 54, 371-377. http://dx.doi.org/10.1590/S1516-89132011000200020

Xia, X.D., Ling, M. J., Xia, M, Hou, M.J., Wang, Q., Zhu, H.L., and Tang, Z.H. 2006. An anthocyanin-rich extract from black rice enhances atherosclerotic plaque stabilization in apolipoprotein E-deficient mice. Journal of Nutrition, 136, 2220-2225. http://dx.doi.org/10.1093/jn/136.8.2220

Yang, J., Martinson, T. E., and Liu, R. H. 2009. Phytochemical profiles and antioxidant activities of wine grapes. Journal of Food Chemistry, 116, 332-339. http://dx.doi.org/10.1016/j.foodchem.2009.02.021

Yim, H.S., Chye, F.Y., Koo, S.M., Matanjunb, P., Howc, S.E. and Hoa, C.W 2012. Optimization of extraction time and temperature for antioxidant activity of edible wild mushroom, Pleurotus porrigens. Food and Bioproducts Processing 90, 235-242. https://doi.org/10.1016/j.fbp.2011.04.001

Yodmanee, S., Karrila, T. T. and Pakdeechanuan, P. 2011. Physical, chemical and antioxidant properties of pigmented rice grown in southern Thailand International Food Research Journal, 18, 869-874.

Zhang w.w, Duan X.J, Huang H.L, Zhang Y and Wang B.G. 2007. Evaluation of 28 marine algae from the Qingdao coast for antioxidative capacity and determination of antioxidant efficiency and total phenolic content of fractions and subfractions derived from Symphyocladia latiuscula (Rhodomelaceae). Journal of Applied Phycology.19, 97-108. http://dx.doi.org/10.1007/s10811-006-9115-x 